\title{
ANAMNESTIC, CLINICAL AND LABORATORY DATA ANALYSIS OF PATIENTS FOR DRUG HYPERSENSITIVITY REACTIONS
}

\author{
ZUBCHENKO S., KRIL I., LOMIKOVSKA M., HAVRYLYUK A., \\ LISCHUK-YAKYMOVICH K., CHOPYAK V. \\ Danylo Halytsky Lviv National Medical University
}

\section{INTRODUCTION}

Adverse drug reactions often occur in both outpatient and inpatient settings and can lead to serious consequences. Among these reactions, drug hypersensitivity reactions (DHRs), are the reaction of the immediate type and are diagnosed in approximately $1-2 \%$ per 100 thousand people. DHRs occur more often among patients who are treated for a long time. The causes of DHRs are often polymorbidity and polypragmatism, which is primarily due to self-medication, over-the-counter drugs, and insufficient coordination of physicians in the management of a patient with polymorbidity $[6,7$, $8,12]$. It is known that viral infections participate in the development of DHRs. On the one hand, in genetically susceptible individuals, viral infections can act as triggers for the onset of DHRs [8, 20]. On the other hand, - alternative theory - the formation of unregulated immune reactions to viruses lead to the development of DHRs. Herpes virus infections are characterized by long-standing persistent in the human body, including - T- and B-cells and can induce immune reactions. DHRs can occur during the reactivation of herpes virus infection and in other cases - the reactivation of these viruses occurs simultaneously or after administration of the drug $[23,27,28]$.

The list of pharmacological drugs that cause harmful reactions in susceptible individuals is constantly growing and includes hundreds of medications [17]. The drug undergoes numerous transformations in the body, it's metabolized and only a certain metabolite is final. Drug side effects can be often allergic, toxic, or mixed responses. Moreover, the reactions that occur are not always accurate evidence of hypersensitivity reactions to a particular drug or metabolite. Competent approaches to diagnosis require clinical evaluation and analysis of anamnestic data, in vivo tests, in particular skin tests (pre-tests, intradermal or patch tests), and provocative tests with a suspicious drug substance. Performing in vivo tests, in particular provocative tests, requires the presence of intensive care units in specialized centers- this is another problem for Ukrainian allergists [9]. Numerous contraindications (especially severe systemic reac- tions) to performing skin allergy tests (SATs) for the diagnosis of immediate-type DHRs, make it impossible to use them routinely. The cause of an allergic reaction, as mentioned above, may not necessarily be the original drug, but its metabolites -so the reliability of SATs is questionable [14]. Therefore, the diagnosis of DHRs together with skin tests often involves the use of other laboratory tests, but to date do not exist reliable in vitro tests [26].

A way of solving the diagnostic problem may be to use a test to determine the expression levels of CD63 on basophils (Basotest) in patients at risk for DHRs and vaccines. The test allows determining the in vitro level of IgE-dependent response to drug allergens in sensitized patients by analyzing the number of activated basophils (by the level of CD63 expression). After stimulation with drug antigen, the level of CD63 expression increases 2-3 times and indicates the risk of hypersensitivity [16, 21]. The results obtained after the determinations of basophils degranulation should be compared with anamnestic and clinical data.

The first stage of our work aimed to analyze the anamnestic, clinical, and laboratory data of patients with DHRs, and herpes virus, and then form groups of patients for the determination of basophils degranulation.

\section{MATERIALS AND METHODS}

The study was conducted following the 7th revision of the principles of the Declaration of Helsinki Human Rights (2013), the Council of Europe Convention on Human Rights and Biomedicine, and relevant laws of Ukraine. Based on the developed international positional documents and the unified clinical protocol "Drug allergy, including anaphylaxis", in 2015 [8] the author's questionnaires were formed:

1. Information letter for primary care physicians, allergists (letters were distributed and published in closed groups for health professionals on social networks).

2. Patient questionnaire card. The map contains detailed anamnestic and clinical data, including indicating drugs that are likely causative allergens; filled in by the patient at the initial 
examination, coordinated, and signed by the doctor.

3. Patient examination card. The map contains detailed data on the patient's health, including on the frequency and manifestations of herpesvirus infections and the characteristics of the clinical manifestations of reactions to a particular drug:

- penicillins/cephalosporins (e.g. Amoxicillin, Ampicillin, Penicillin, Cefazolin, Ceftriaxone, Cefalexin, Cefuroxime, etc.);

- fluoroquinolones (e.g. Moxifloxacin, Ciprofloxacin, etc.);

- X-ray contrast agents (e.g. Ultravist, Vizipak, Omnipak, Tomohexol, Gadolinium, etc.)

- narcotic analgesics and muscle relaxants (e.g. Propofol, Atracurium, etc.);

- local anesthetics (e.g. Artikain, Mepivacaine, Lidocaine, Novocaine, etc.);

- other medications.

This card is filled in during the second visit of the patient by the allergist participating in the study.

At the initial request to doctors of various profiles, 368 patients were examined during the six months of 2021 and referred to allergists of the Department of Clinical Immunology and Allergology, Danylo Halytskyy Lviv National Medical University.

$32(8.70 \%)$ patients at risk of DHRs were selected based on the processing of the data of the "Patient Questionnaire Card", including 18 (56.3\%) women and $14(43.7 \%)$ men, whose average age was $33 \pm 9.5$ years

Inclusion criteria in the study were: development of allergic reactions to medications/vaccines no longer than three years before beginning the study (immediate-reactions such as anaphylaxis or anaphylactic shock, angioedema, bronchospasm, acute urticaria that occur less than 1 hour after the last drug intake; age from 18 to 60 years; written informed consent to participate in the study.

The exclusion criteria were: pregnancy; mental disorders in the patient; taking medications that may affect the activations of the basophils (antihistamines, corticosteroids, and cromoglycic acid derivatives should be excluded two weeks before blood sampling).

Comprehensive clinical and laboratory and molecular genetic examinations to all patients were undergoing. Total IgE, specific antibodies to VCA IgG and EBNA IgG were determined by enzyme-linked immunosorbent assay (ELISA) using reagents from "Euroimmun" (Germany), according to the manufacturer's instructions. The EBV DNA determination in blood, saliva, and the posterior pharyngeal wall were performed by polymerase chain reaction (PCR) by GeneProof Epstein-Barr Virus (EBV) PCR Kit (Czech Republic) using "Rotor-Gene 6000" (Corbett Research, Australia). 25 healthy people of appropriate age and sex consist of the control group. The research results were analyzed by the variation statistics method using the STATISTICA 10 (Statsoft, USA) and Student's t-test.

Research results and discussion. Based on the processing of personal data, it was found that most often among the patients in the study were hypersensitivity reactions to antibiotics in $16(50.0 \%)$ patients, to X-ray contrast agents in $8(25.0 \%)$ patients, in $4(12.5 \%)$ patients to perioperative drug and local anesthetics in 4 (12.5\%) patients, Fig. 1.

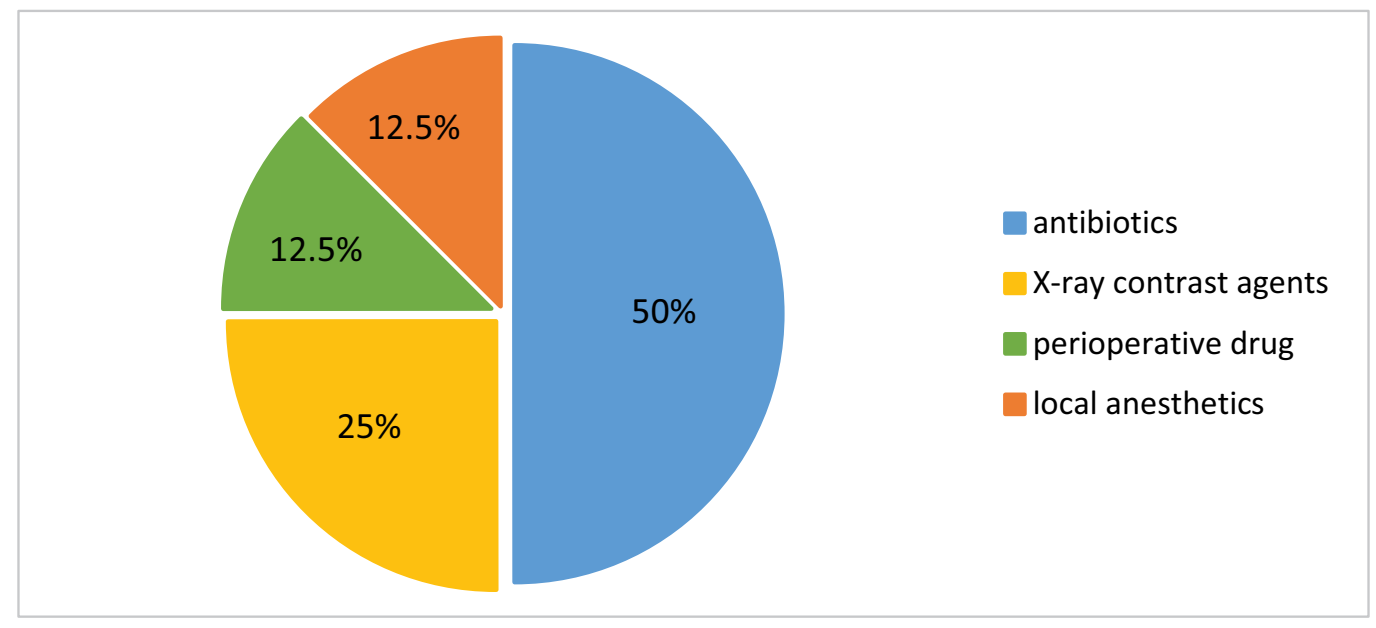

Fig 1. Prevalence of DHRs in the group, $n=32$

In the vast majority of cases (58.3\%) the hypersensitivity reactions occurred to intravenous and intramuscular administration of medication. Generally, patients have noted the reactions when they have taken a particular drug once or twice.
In other cases, it was difficult for patients to answer the questions about the use of a particular drug and they only named the appropriate group of medications. From the literature data and our observations, we know that the development of 
DHRs may be accompanied by the cross-reactions between medications that have the same determinant, which is most often observed among antibacterial drugs [1, 2]. Moreover, the level of cross-reaction of patients with a penicillin allergy is higher when taking carbapenems, average when taking cephalosporins, and minimal - when taking monobactams [3]. In our case, the most common cause of DHRs were antibiotics, namely -lactams (cephalosporins, synthetic penicillins, monobactams, carbapenems). This is primarily due to taking antibiotics starting from early childhood. The primary sensitization with a high probability is consuming foods and beverages that contain antibiotics. Should also take into account, that the patient doesn't know about the presence of antibiotic preservatives in food, and the information on the label is not always true [10]. Clinical manifestations of DHRs in $50.0 \%$ of patients occurred 10-20 minutes after taking the causative drug. In three $(9.37 \%)$ patients, the symptoms of DHRs appeared up to 5 minutes after taking the drug, in other patients - after 30 minutes. In the clinical data analysis of patients was revealed that the manifestations of DHRs were more common: urticaria, accompanied by angioedema - 40.6\%, urticaria - $28.1 \%$, anaphylaxis $-21.9 \%$, obstructive bronchitis changes $-9.37 \%$, Fig. 2 .

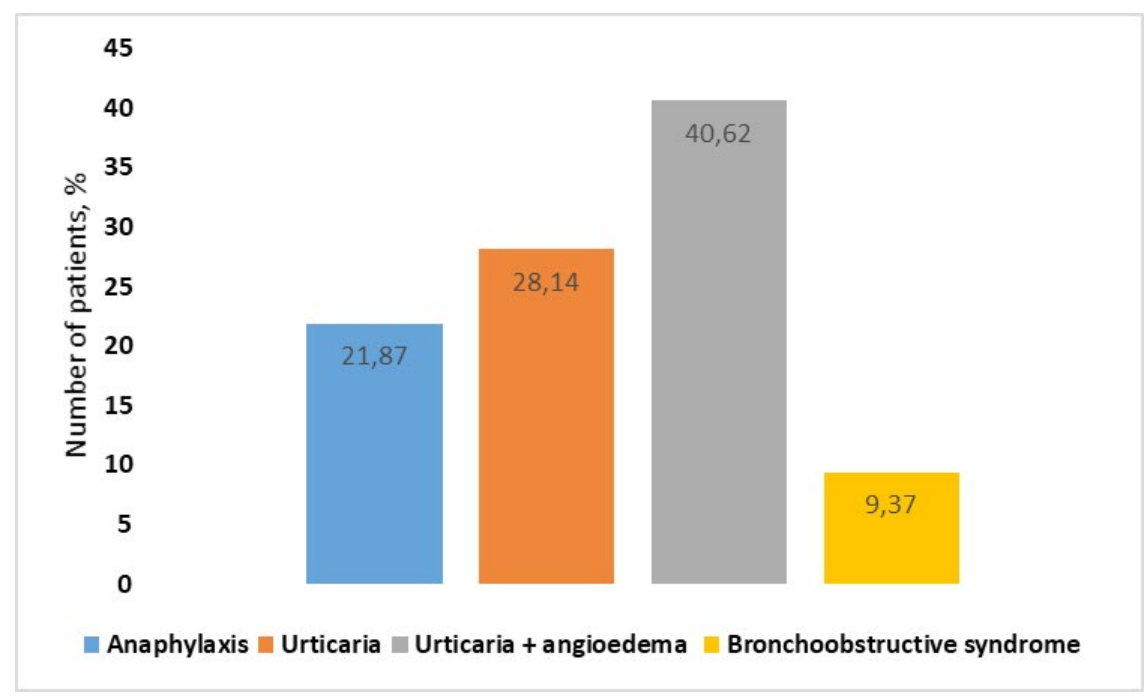

Fig.2. Prevalence of clinical manifestations of DHRs in the group, $n=32$

Patients usually display a polysymptomatic clinical picture. In particular, urticaria was characterized by itching, with more frequent (53.1\%) localization in the torso and upper extremities. In $12.5 \%$ of patients, urticaria was accompanied by flushing and hyperthermia. In $65.6 \%$ of patients manifestations of angioedema on the face were found - not symmetrical, more often located in areas of soft tissues (eyelids, lips); in 15.6\% of patients, facial edema was combined with edema of the external genitalia and distal parts of the extremities, and in $18.9 \%$ patients facial edema was combined with edema of the mucous membrane of the upper respiratory tract and tongue. Patients with obstructive bronchitis changes complain of shortness of breath, dry cough. Some patients experienced tightness in the chest, heart palpitations, and anxiety. In patients with anaphylaxis and arterial hypotension, the detailed clinical features were characterized by a combination of manifestations of the skin - in $85.7 \%$ of cases, respiratory - in $71.4 \%$, cardiovascular system - in $57.1 \%$ and digestive tract (vomiting, pain, and abdominal discomfort) - in 28 . $6 \%$ of cases. A detailed anamnestic data analysis displays $25.0 \%$ of patients regularly use a sedative and antihypertensive treatment, NSAIDs, antihistamines, intranasal decongestants or corticosteroids, contraceptives, etc.

According to the questionnaire data, it was also found that 12 (37.5\%) patients had chronic diseases, mainly: diseases of the thyroid gland (autoimmune thyroiditis), cardiovascular system (hypertension), diabetes mellitus, diseases of the gastrointestinal tract. Allergic diseases were detected in five patients $-15.6 \%$ (allergic rhinitis (AR), asthma, allergic dermatitis).

Patients with DHRs also declared frequent viral infections. ARI more than 8 times a year occurred in $62.5 \%$ of patients, virus infections (labial and nasal herpes manifestations caused by herpes simplex virus type 1 (HSV-1) four and more times a year in $34.4 \%$ of patients, low-grade fever - in $12.5 \%$, chronic fatigue syndrome (CFS) - in $68.7 \%$ of patients. $21.9 \%$ of patients mentioned acute stress reaction before taking the drug, and $59.4 \%$ of patients were in chronic stress. Photosensitivity reactions were noted in $9.40 \%$ of patients, increased 
sweating - in 9.40\%, emotional lability (often irritability, tearfulness, feelings of horror, fear, etc.) in $18.6 \%$ of patients. In most $(78.1 \%)$ patients the family history was not burdened, except for three people which close relatives declared asthma and allergic rhinitis, and DHRs.

As previously mentioned, the majority of patients with DHRs were in chronic stress or were exposed to acute stress. It is known about changes in the immune response during stress. An alternative theory describes that people with a constitutional and genetic predisposition to DHRs in response to the taking of medications develop acute or chronic stress. It's manifested by conformational changes in the protein structure of the cells and emotional overload that leads to dysfunction of the diencephalic stem, including the brain. which causes increased production of adrenocortical and gonadotropic hormones and depletes the adrenal cortex [11]. In this way, DHRs can be considered a disease of adaptation, which occurred in some patients.

According to common lab tests, in 17 (53.1\%) patients was found lymphocytosis, in two (6.25\%) had lymphopenia, five (15.6\%) had monocytosis, and three $(9.37 \%)$ had mild eosinophilia.

The leading role in the processes of drug biotransformation belongs to the liver. Most drugs are metabolized in the liver due to the presence of various enzymes in the endoplasmic reticulum of hepatocytes. The most favorable conditions for the occurrence of DHRs have been created due to a certain phenotype of enzyme systems, among which a special role is played by the system of cytochrome P-450, Iysosomal enzymes, liver transferases. Activation of enzymes stimulates lipid peroxidation reactions, which leads to disruption of intracellular metabolism and increases the risk of medications complications [4]. Biochemical analysis of blood elicited that $5(15.6 \%)$ patients had elevated levels of AST and ALT [5].

It is known that the key immunological mechanisms by P. Gell, R. Coombs (1968, 1975) classification include the immediate (atopic) type that is mediated by IgE antibodies, antibody-mediated cytotoxic reaction, immune complex-mediated reaction, delayed-type hypersensitivity (DTH). According to the recent data literature, DHRs mostly (77.0\% patients) develop according to the immediate type of immune pathological reactions, in 5\% -developed by immune complex-mediated reaction and in $9 \%$ patients - by DTH [6]. In patients with DHRs often observed a combination of several types of immune pathological reactions, one of which predominates [19]. According to our results, the level of total serum IgE was elevated in $78.1 \%$ of patients with values of $147-1023 \mathrm{kU} / \mathrm{l}$, which corresponded to the data of the scientific literature and indicated the key role of the immediate type in the formation of DHRs.
As mentioned above, $34.4 \%$ of patients observed frequent manifestations of infection caused by HSV-1 type. According to the literature data, $\mathrm{HSV}$ reactivation is most often associated with drug reaction with eosinophilia and systemic symptoms (DRESS) syndrome [22]. However, other authors did not observe these patterns [13]. Some reports describe an association of chronic EBV infection in the active phase with DHRs and the authors' conclusions are also controversial. The most common manifestations of DHR (especially antibiotics) are maculopapular exanthemas [8]. Most researchers argue that the presence of chronic active EpsteinBarr virus infection can cause severe DHRs. The authors of V Descamps, E Mahe (2003) described the corresponding manifestations after the patient took allopurinol [15].

Studies by Yoko Kano and Miyuki Inaoka (2006) have shown a link between hypersensitivity reactions to intravenous immunoglobulins and reactivated herpesviruses, including EBV [20]. Recent reports suggest a close association between the reactivation of human herpes viruses, most often type 6 (HHV-6), as well as HHV-7, EBV, cytomegalovirus (CMV) with the development of DRESS [18]. Instead, the authors of Ozcan D, Se kin D (2010) noted that only HHV-6 in the active phase can initiate DHRs and did not confirm the association of these reactions with EBV. On the contrary, there is also evidence that DHRs initiate the reactivation of herpes virus infections (HHV-6, HHV-7, CMV, and EBV), which is accompanied by a more severe course [24]. In support of this report, Y Kano, $\mathrm{K}$ Hiraharas, (2006) concluded that the sequential reactivation of these herpesviruses is responsible for the development of multiorgan failure, which is formed after the cessation of the drug allergen action [20].

Therefore, we decided to research the probable participation of EBV in the DHRs formation. So, all patients underwent studies of serological and PCR EBV. Serological studies displayed that IgG antibodies to nuclear antigen (EBNA-IgG) were detected in $100 \%$ of patients, indicating a significant prevalence of EBV in adult patients with DHRs. In 19 (59.4\%) patients were detected EBV DNA positive, of which: $3(15.8 \%)$ - in posterior pharynx mucosa, $4(21.1 \%)$ - in saliva, $10(52.6 \%)$ patients - in saliva + mucosa simultaneously, $2(10.5 \%)$ - in blood + other biological media (the number of copies of EBV DNA ranged from $<500$ to 107 ), which indicated for the presence of chronic active EBV infection (Fig. 3,4). The latent phase of chronic EBV infection was detected in 13 patients, which is characterized by the absence of EBV DNA. 


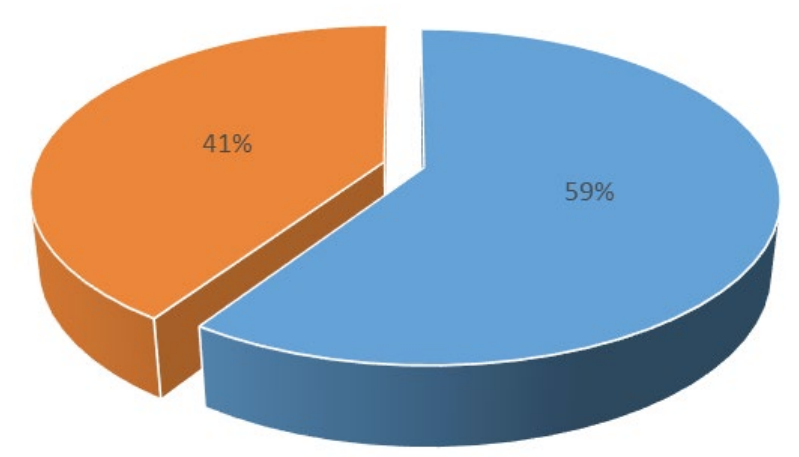

- serological positive = serological negative

Fig.3 The result of serological investigations of chronic EBV infection

Finally, among patients with DHRs, the chronic EBV infection was detected in all patients and more than half $(59.4 \%)$ revealed an active phase of EBV. An anamnestic and clinical data showed that patients with chronic active EBV infection were more likely to complain of general weakness - in $78.9 \%$, fatigue - in $63.1 \%$, headache, and dizziness - in $52.6 \%$, prolonged low-grade fever - in $21.1 \%$, joint and muscle pain - in $26.3 \%$, sore throat and itching $-84.2 \%$, cognitive impairment $-15.7 \%$, frequent ARI ( 8 and more times in year) - in $89.5 \%$ of patients, etc. Additional immunological studies revealed decreased phagocytic activity and lymphocyte population altered in these patients. The results of the studies indicated the formation of EBV-associated secondary immune disorders in patients with DHRs and the active chronic EBV infection.

The second stage of our research is performing the quantitative determination of basophil degranulation in heparinized human whole blood. in serum of patients detect the level of expression tryptase, II-4, and -5 using ELISA.

\section{CONCLUSIONS:}

1. DHRs among patients are most often detected to antibiotics (50.0\%) and X-ray contrast agents $(27.7 \%)$, to a lesser extent to perioperative drugs and local anesthetics $-13.6 \%$.

2. Clinical manifestations of DHRs were - urticaria with angioedema $(40.6 \%)$, urticaria $(28.1 \%)$, anaphylaxis $(21.9 \%)$, obstructive bronchitis changes $(9.37 \%)$. The elevated levels of total IgE were observed in $78.1 \%$ of patients with DHRs.

3. Patients with DHRs revealed features of clinical and laboratory data, including frequent manifestations of herpes infection HSV-1 (34.4\%), chronic fatigue syndrome $(68.7 \%)$, frequent viral infections $(62.5 \%)$, exposure to

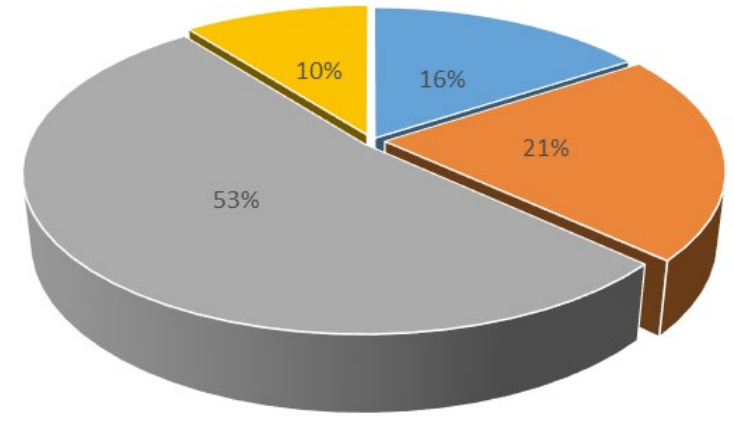

osterior pharyngeal mucosa " saliva " saliva+mucosa " blood+other $\mathrm{m}$

Fig. 4 PCR results of chronic EBV infection

chronic stress (59.4\%), etc. The general blood analysis revealed alterations in the number of lymphocytes $(59.4 \%)$ and transaminases biochemical activity $(15,6 \%)$.

4. The chronic EBV infection was among all patients with DHRs and $59.4 \%$ of patients demonstrated an active phase of the virus, which was accompanied by manifestations of EBV-associated secondary immune disorders.

\section{REFERENCES}

1. Вікторов О.П. Алергічні реакції на лікарські засоби: сучасні проблеми. Новости медицины и фармации. 2006;16:14-16.

2. Вікторов О.П., Кучер В.Г., Кашуба О.В. Мелоксикам: безпека при медичному застосуванні як основа раціональної фармакотерапії. Рациональная фармакотерапия. 2007;4:14-17.

3. Викторов А.П., Посохова К.А., Матвеева Е.В., Логвина И.А. Побочные действия антибиотиков группы цефалоспоринов в Украине. Итоги 2005 года. Острые и неотложные состояния в практике врача. 2006;2:66-67.

4. Давидюк А.В., Горчаков Н.О., Чекман І.С. Застосування метаболічних препаратів у фармакотерапії туберкульозу. Раціональна фармакотерапія. 2016;2 (39):41-44.

5. Кушнір I.E. Медикаментозне ураження печінки: епідеміологія, клінічніпрояви, діагностичні критерії та принципи лікування. Здоров'я України. «Гастроентерологія. Гепатологія. Колопроктологія». 2020;1(55):10-12.

6. Матвєєва О.В., Вікторов О.П., Бліхар В.Є. Міжнародний та вітчизняний досвід діагностики та профілактики алергічних побічних реакцій. Новости медицины и фармации. 2011;10:2-4. 
7. Матвєєва О.В., Вікторов О.П., Бліхар В.Є. Оцінка поінформованості лікарів України щодо побічних реакцій алергічного ґенезу. Новости медицины и фармации. 2011;1112:2-4.

8. Наказ МОЗ України від 30.12.2015 № 916 Уніфікований клінічний протокол екстреної, первинної, вторинної (спеціалізованої) та третинної (високоспеціалізованої) медичної допомоги «Медикаментозна алергія, включаючи анафілаксію».

9. Пухлик Б.М., Дидятківська Є.М., Пухлик С.М. Медикаментозна алергія: Стан проблеми, організація виявлення, діагностика, профілактика і лікування (методичні рекомендації). Київ, 2007: 27.

10. Радченко О.М. Медикаментозна алергія. Раціональна фармакотерапія. 2016;1(38):512.

11. Солошенко Э.Н. Побочное действие лекарственные средств. Дифференциальная диагностика аллергических, токсико-аллергических и псевдоаллергических реакций. Клінічна імунологія. Алергологія. Інфектологія. 2007;1:8-14.

12. Хаджинова Н.А., Чайковська В.В. Кількісна оцінка призначень медикаментозних засобів пацієнтам літнього віку в умовах амбулаторій загальної практики - сімейної медицини. Ліки України. 2007;109:56-57.

13. Chen $Y C$, Chiang $H H$, Cho $Y T$, Chang $C Y$, Chen KL, Yang CW et al. Human herpes virus reactivations and dynamic cytokine profiles in patients with cutaneous adverse drug reactions a prospective comparative study Allergy. 2015 May;70(5):568-75. doi: 10.1111/all.12602.

14. Demoly P, Adkinson NF, Brockow K, Castells M,. Chiriac AM,. Greenberger PA et al. International Consensus on drug allergy. Allergy. 2014;69:420-437.

15. Descamps V, Mahe E, Houhou N, Abramowitz L, Rozenberg F, RangerRogez S. Drug-induced hypersensitivity syndrome associated with Epstein-Barr virus infection. Affiliations expand $\mathrm{Br} J$ Dermatol. 2003 May;148(5):1032-4. doi: 10.1046/j.1365-2133.2003.05330.x.

16. De Weck AL, Sanz ML, Gamboa PM et al. Nonsteroidal anti-inflammatory drug hypersensitivity syndrome: a multicenter study. II. Basophil activation by nonsteroidal antiinflammatory drugs and its impact on pathogenesis. J. Investig. Allergol. Clin. Immunol. 2010;20: 39-57.

17. Doña I., Barrionuevo E., Blanca-Lopez N. Trends in hypersensitivity drug reactions: more drugs, more response patterns, more heterogeneity. Investig. Allergol. Clin. Immunol. 2014;24(3):143-153.

18. Draz $N$, Sumona Datta $S$, Daniel $P$, Webster DP, and lan Cropley I. Drug reaction with eosinophilia and systemic symptoms (DRESS) syndrome secondary to antituberculosis drugs and associated with human herpes virus-7 (HHV-7). BMJ Case Rep. online 2013 Jul 31. doi: 10.1136/bcr-2013010348.

19. Drug Allergy: Diagnosis and management of drug allergy in adults, children and young people. London: National Institute for Health and Care Excellence (UK). 2014. Електр. pecypc: http://www.ncbi.nlm.nih.gov/ pubmed/2534022621.

20. Kano $Y$, Hiraharas $K$, Sakuma $K$, Shiohara $T$. Several herpesviruses can reactivate in a severe drug-induced multiorgan reaction in the same sequential order as in graftversus-host disease. $\mathrm{Br} \mathrm{J}$ Dermatol. 2006 Aug;155(2):301-6. doi: 10.1111/j.13652133.2006.07238.x.

21. Leysen J, Sabato V, Verweij M, De Knop JK, Bridts $\mathrm{CH}$, Luc $S$ et al. The basophil activation test in the diagnosis of immediate drug hypersensitivity. Exp Rev. Clin. Immunology. 2011, May;7(3):349-356.

22. Maiko Kurata, Tetsuo Shiohara. Herpes simplex virus reactivation: is it common or rare in drug-induced hypersensitivity syndrome/drug reaction with eosinophilia and systemic symptoms? Eur J Dermatol. 2017 Dec 1;27(6):658-659. doi: 10.1684/ ejd.2017.3117.

23. Ozcan D, Se kin D, Bilezik i B, Arslan H. The role of human herpesvirus-6, Epstein-Barr virus and cytomegalovirus infections in the etiopathogenesis of different types of cutaneous drug reactions. Int J Dermatol. 2010 Nov;49(11):1250-4. doi: 10.1111/j.13654632.2010.04531.x.

24. Seishima $M$, Yamanaka $S$, Fujisawa $T$, Tohyama $M$, Hashimoto $K$. Reactivation of human herpesvirus (HHV) family members other than HHV-6 in drug-induced hypersensitivity syndrome. $\mathrm{Br} \mathrm{J}$ Dermatol. 2006, Aug;155(2):344-9. doi: 10.1111/j.13652133.2006.07332.x.

25. Tawhari I, Tawhari F, Aljuaid M. Lamotrigineinduced drug reaction with eosinophilia and systemic symptoms (DRESS) during primary Epstein-Barr virus (EBV) infection. BMJ Case Rep. 2018 Jan 23;2018:bcr2017222416. doi: $10.1136 / \mathrm{bcr}-$ 2017-222416. 
26. Wong Diane L, Seger, Kenneth H Lai, Foster $R$ Goss, Kimberly G Blumenthal, Li Zhou. Drug Hypersensitivity Reactions Documented in Electronic Health Records within a Large Health System Adrian Clin Immunol Pract J Allergy. 2019 Apr;7(4):1253-1260.e3. doi: 10.1016/j.jaip.2018.11.023.

27. Yoko Kano, Miyuki Inaoka, Keiichi Sakuma, Tetsuo Shiohara. Virus reactivation and intravenous immunoglobulin (IVIG) therapy of drug-induced hypersensitivity syndrome Toxicology. 2005 Apr 15;209(2):165-7. doi: 10.1016/j.tox.2004.12.013.

28. Zubchenko S, Potemkina G, Havrylyuk A, Lomikovska $M$, Sharikadze $O$. Analysis of the level of cytokines with antiviral activity in patients with allergopathology in active and latent phases of chronic persistent Epstein-Barr infection. Georgian Med News. 2019;4(289):158-62. https://pubmed.ncbi. nlm.nih.gov/31215899/.

29. Наказ МОЗ України від 30.12.2015 № 916 Уніфікований клінічний протокол екстреної, первинної, вторинної (спеціалізованої) та третинної (високоспеціалізованої) медичної допомоги «Медикаментозна алергія, включаючи анафілаксію»

\section{SUMMARY}

\section{ANAMNESTIC, CLINICAL AND LABORATORY DATA ANALYSIS OF PATIENTS FOR DRUG HYPERSENSITIVITY REACTIONS \\ Zubchenko S., Kril I., Lomikovska M., Havrylyuk A. Lischuk-Yakymovich K., Chopyak V. \\ Danylo Halytsky Lviv National Medical University}

The current development of the pharmaceutical industry in the synthesis of new chemical compounds, standardized treatment protocols, and disease prevention can lead to a progressive increase in drug hypersensitivity reactions, which often have serious consequences for human health. Increasing evidence of involvement of infections, including Herpesviridae viruses, in the development of drug hypersensitivity reactions is known.

The method of flow cytometry can be used, in particular, the basophil activation test to diagnose drug hypersensitivity reactions. The anamnestic, clinical, and laboratory data of 368 people were analyzed for the selection of patients at risk of drug hypersensitivity for the basophil degranulation test execution. It was found that among patients hypersensitivity reactions were most often detected to antibiotics (50.0\%), radiopaque substances (27.7\%), perioperative drugs, local anesthetics - $13.6 \%$ each. Clinical manifestations of these reactions were urticaria with angioneurotic edema $(40.6 \%)$, urticaria $(28.1 \%)$, anaphylaxis $(21.9 \%)$, obstructive bron- chitis chenges (9.37\%). According to anamnestic and clinical-laboratory data, patients with a high risk of drug hypersensitivity reactions revealed frequent manifestations of herpesvirus infection HSV1 (34.4\%), active chronic persistence of EBV (59.4\%), accompanied by manifestations of EBV-associated secondary immune disorders and prevalence of chronic EBV infection in all patients.

Key words: drug allergy, DHRs, basophils degranulation test, herpesvirus infection.

\section{PEЗЮME}

\section{АНАЛІЗ АНАМНЕСТИЧНИХ I КЛІНІКО- ЛАБОРАТОРНИХ ДАНИХ ПАЦІЕНТІВ ГРУПИ РИЗИКУ РЕАКЦІЙ ГІПЕРЧУТЛИВОСТІ ДО ЛІКАРСЬКИХ ЗАСОБІВ}

Зубченко С.О., Кріль І.Й., Ломіковська М.П., Гаврилюк А.М., Ліщук-Якимович Х.О., Чопяк В.В.

Львівський національний медичний університет імені Данила Галицького

Сучасні темпи розвитку фармацевтичної індустрії щодо синтезу нових хімічних сполук, стандартизація лікування і профілактики хвороб призвела до прогресивного росту медикаментозної алергії (МА), яка часто носить серйозні наслідки для здоров'я людини. Описано все більше доказів участі інфекцій, у тому числі вірусів родини Herpesviridae у розвитку реакцій гіперчутливості до лікарських засобів (ЛЗ). Проблема діагностики МА із застосуванням альтернативних методів, зокрема тесту активації базофілів, $є$ актуальною для вітчизняної медицини.

3 метою відбору пацієнтів груп ризику реакцій гіперчутливості на ЛЗ і проведення базотесту проаналізовано анамнестичні, клінічні та лабораторні дані 368 осіб. Встановлено, що реакції гіперчутливості серед пацієнтів групи ризику (32 особи) найчастіше виявлені до антибіотиків $(50,0 \%)$, рентгеноконтрасних речовин $(27,7 \%)$, периопераційних препаратів і місцевих анестетиків - по 13,6\%. Клінічними проявами цих реакцій були - кропив'янка з ангіонабряком $(40,6 \%)$, кропив'янка $(28,1 \%)$, анафілаксія $(21,9 \%)$, бронхообструктивний синдром (9,37\%). У пацієнтів групи ризику виявлено особливості анамнестичних і клініко-лабораторних даних, часті прояви герпетичної інфекції HSV 1/2 (34,4\%) і значну (100\%) поширеність хронічної EBV-інфекції, в т.ч. в активній фазі персистенції вырусу (59,4\%), що супроводжувалось проявами EBV-асоційованих вторинних імунних порушень.

Ключові слова: медикаментозна алергія, групи ризику реакцій гіперчутливості до лікарських засобів, базотест, герпесвірусна інфекція. 


\section{PЕЗЮME \\ АНАЛИЗ АНАМНЕСТИЧЕСКИХ И КЛИНИКО- ЛАБОРАТОРНЫХ ДАННЫХ ПАЦИЕНТОВ ГРУППЫ РИСКА РЕАКЦИЙ ГИПЕРЧУВСТВИТЕЛЬНОСТИ К ЛЕКАРСТВЕННЫМ ПРЕПАРАТАМ}

Зубченко С.А., Криль И.И., Ломиковская М.П., Гаврилюк А.М., Лищук-Якимович Х.А., Чопяк В.В.

Львовский национальный медицинский университет имени Данила Галицкого

Современные темпы развития фармацевтической индустрии - синтез новых химических соединений, стандартизация лечения и профилактики болезней привели к прогрессивному росту медикаментозной аллергии (МА), которая часто носит серьезные последствия для здоровья человека. Существует все больше доказательств участия инфекций, в том числе вирусов семейства Herpesviridae в развитии реакций гиперчувствительности к лекарственным препаратам (ЛП). Проблема диагностики МА с применением альтернативных методов, в частности теста активации базофилов, является актуальной для отечественной медицины.
С целью отбора пациентов групп риска реакций гиперчувствительности к ЛП и постановки базотеста проанализированы анамнестические, клинические и лабораторные данные 368 пациентов. Установлено, что реакции гиперчувствительности у больных группы риска (32 лиц) чаще были к антибиотикам (50,0\%), рентгеноконтрастным веществам $(27,7 \%)$, периоперационным препаратам и местным анестетикам - по 13,6\%. Клиническими проявлениями этих реакций были - крапивница с ангионевротическим отеком (40,6\%), крапивница $(28,1 \%)$, анафилаксия $(21,9 \%)$, бронхообструктивный синдром (9,37\%). У пациентов группы риска выявлены особенности анамнестических и клинико-лабораторных данных, частые проявления герпетической инфекции HSV $(34,4 \%)$ и значительная (100\%) распространенность хронической EBV-инфекции, в т.ч. в активной фазе персистенции вируса (59,4\%), что сопровождалось проявлениями EBV-ассоциированных вторичных иммунных нарушений.

Ключевые слова: медикаментозная аллергия, группы риска реакций гиперчувствительности к лекарственным препаратам, базотест, герпесвирусная инфекция.

\section{АВТОРСЬКА ДОВІДКА}

\section{- Зубченко Світлана Олександрівна}

к.м.н, доцент кафедри клінічної імунології та алергології Львівського національного медичного університету імені Данила Галицького

Адреса: вул. Пекарська, 69, Львів,

Львівська область, 79010, Україна

Моб. тел.: +38 0676706643

E-mail: svitlana_zu@meta.ua http://orcid.org/0000-0003-4471-4884

\section{- Кріль Ірина Йосифівна}

к.б.н, старший науковий співробітник кафедри клінічної імунології та алергології Львівського національного медичного університету імені Данила Галицького Адреса: вул. Пекарська, 69, Львів, Львівська область, 79010, Україна

Моб. тел..: +38 0678348916

E-mail: kril.iryna@ukr.net

http://orcid.org/0000-0002-6728-5827

\footnotetext{
- Ломіковська Марта Павлівна

к.м.н, асистент кафедри клінічної імунології та алергології Львівського національного медичного університету імені Данила Галицького

Адреса: вул. Пекарська, 69, Львів, Львівська область, 79010, Україна

Моб. тел.: +38 0972357477

E-mail: ydmarta79@gmail.com

https://orcid.org/0000-0002-9850-069X
}

\section{- Зубченко Светлана Александровна}

к.м.н., доцент кафедры клинической иммунологии и аллергологии Львовского национального медицинского университета имени Даниила Галицкого Адрес: ул. Пекараская, 69, Львов, Львовская область, 79010, Украина Моб. тел.: +38 0676706643 E-mail: svitlana_zu@meta.ua http://orcid.org/0000-0003-4471-4884

\section{- Криль Ирина Иосифовна}

к.б.н., старший научний сотрудник кафедры клинической иммунологии и аллергологии Львовского национального медицинского университета имени Даниила Галицкого Адрес: ул. Пекараская, 69, Львов, Львовская область, 79010, Украина

Моб. тел..: +38 0678348916

E-mail: kril.iryna@ukr.net

http://orcid.org/0000-0002-6728-5827

\footnotetext{
- Ломиковская Марта Павловна к.м.н., ассистент кафедры клинической иммунологии и аллергологии Львовского национального медицинского университета имени Даниила Галицкого Адрес: ул. Пекараская, 69, Львов, Львовская область, 79010, Украина

Моб. тел.: +38 0972357477

E-mail: ydmarta79@gmail.com https://orcid.org/0000-0002-9850-069X
}

\section{- Zubchenko Svitlana}

PhD Associate Professor, Department of Clinical Immunology and Allergology, Danylo Halytsky Lviv National Medical University Address: st. Pekarska, 69, Lviv, Lviv region, 79010, Ukraine

Tel.: +3806767066 43

E-mail: svitlana zu@meta.ua http://orcid.org/0000-0003-4471-4884

\author{
- Kril Iryna \\ Candidate of Biological Sciences, Department \\ of Clinical Immunology and Allergology, Danylo \\ Halytsky Lviv National Medical University \\ Address: st. Pekarska, 69, Lviv, Lviv region, \\ 79010, Ukraine \\ tel.: +380678348916 \\ E-mail: kril.iryna@ukr.net \\ http://orcid.org/0000-0002-6728-5827
}

\section{- Lomikovska Marta \\ Assistant, Department of Clinical Immunology and Allergology, Danylo Halytsky Lviv National Medical University \\ Address: st. Pekarska, 69, Lviv, Lviv region, 79010, Ukraine tel.: +38 0972357477 E-mail: ydmarta79@gmail.com https://orcid.org/0000-0002-9850-069X}




\section{- Гаврилюк Анна Мирославівна} д.біол.н., професор кафедри клінічної імунології та алергології Львівського національного медичного університету імені Данила Галицького

Адреса: вул. Пекарська, 69, Львів, Львівська область, 79010, Україна

Моб. тел.: +38 0677573943

E-mail: ahavrylyuk@meta.ua

https://orcid.org/0000-0001-9808-8896

\section{- Ліщук-Якимович Христина Олександрівна}

к.м.н, доцент кафедри клінічної імунології та алергології Львівського національного медичного університету імені Данила Галицького Адреса: вул. Пекарська, 69, Львів, Львівська область, 79010, Україна

Моб. тел.: +38 0671512468

E-mail: k_yakymovych@ukr.net

https://orcid.org/0000-0001-7347-7238

\section{- Чопяк Валентина Володимирівна}

д.мед.н., професор кафедри клінічної імунології та алергології Львівського національного медичного університету імені Данила Галицького

Адреса: вул. Пекарська, 69, Львів, Львівська область, 79010, Україна

Моб. тел.: +38 0672801043

E-mail: chopyakv@ukr.net

http://orcid.org/0000-0003-3127-2028
- Гаврилюк Анна Мирославовна

д.биол. наук, профессор кафедры клинической иммунологии и аллергологии Львовского национального медицинского университета имени Даниила Галицкого

Адрес: ул. Пекараская, 69, Львов, Львовская область, 79010, Украина

Моб. тел.: +38 0677573943

E-mail: ahavrylyuk@meta.ua https://orcid.org/0000-0001-9808-8896

\section{- Лищук-Якимович Кристина Александровна}

к.м.н., доцент кафедры клинической иммунологии и аллергологии Львовского национального медицинского университета имени Даниила Галицкого Адрес: ул. Пекараская, 69, Львов, Львовская область, 79010, Украина

Моб. тел.: +38 0671512468

E-mail: k yakymovych@ukr.net https://orcid.org/0000-0001-7347-7238

\section{- Чопяк Валентина Владимировна}

д.мед.н., профессор кафедры клинической иммунологии и аллергологии Львовского национального медицинского университета имени Даниила Галицкого

Адрес: ул. Пекараская, 69, Львов, Львовская область, 79010, Украина

Моб. тел.: +380672801043

E-mail: chopyakv@ukr.net http://orcid.org/0000-0003-3127-2028

\section{- Havrylyuk Anna}

Doctor of Biological Sciences, Professor, Department of Clinical Immunology and Allergology, Danylo Halytsky Lviv National Medical University

Address: st. Pekarska, 69, Lviv, Lviv region, 79010, Ukraine

tel.: +380677573943

E-mail: ahavrylyuk@meta.ua https://orcid.org/0000-0001-9808-8896

\section{- Lischuk-Yakymovych Kristina}

$\mathrm{PhD}$ Associate Professor, Department of Clinical Immunology and Allergology, Danylo Halytsky Lviv National Medical University Address: st. Pekarska, 69, Lviv, Lviv region, 79010, Ukraine Tel.: +38 0671512468

E-mail: k_yakymovych@ukr.net https://orcid.org/0000-0001-7347-7238

\section{- Chopyak Valentyna}

MD of Sciences, Professor, Department of Clinical Immunology and Allergology, Danylo Halytsky Lviv National Medical University Address: st. Pekarska, 69, Lviv, Lviv region, 79010, Ukraine

Tel.: +380672801043

E-mail: chopyakv@ukr.net http://orcid.org/0000-0003-3127-2028 